\title{
A temporally controlled $\sigma$-factor is required for polar morphogenesis and normal cell division in Caulobacter
}

\author{
Yves V. Brun and Lucille Shapiro \\ Department of Developmental Biology, Beckman Center, Stanford University School of Medicine, Stanford, California \\ 94305-5427 USA
}

\begin{abstract}
The transcription of many spatially and temporally controlled flagellar structural genes in Caulobacter requires the RNA polymerase $\sigma^{54}$ subunit. Like flagellar biogenesis, stalk formation is an asymmetric polar morphogenesis that occurs once each cell cycle in response to internal cell cycle signals. We have isolated the $\sigma^{54}$ gene $(\boldsymbol{r p o N})$ and describe here a novel role for this alternative $\sigma$-factor in cell differentiation: It is required for the biogenesis of both polar structures, and the disruption of the rpoN gene results in aberrant cell division. Surprisingly, the transcription of $\operatorname{rpoN}$ is temporally regulated during the cell cycle; it increases 10-fold commensurate with stalk formation and just before the onset of flagellar gene expression. These results suggest that $\sigma^{54}$ abundance responds to cell cycle cues and is involved in the global timing of the central events of Caulobacter development, whereas the transcriptional activators of $\sigma^{54}$-dependent promoters are responsible for the refined control of the expression of individual or small groups of genes required for each specific event.
\end{abstract}

[Key Words: Caulobacter; rpoN; $\sigma^{54}$; stalk; flagellum; differentiation]

Received August 12, 1992; revised version accepted September 15, 1992.

Cellular differentiation exhibited by the bacterium Caulobacter crescentus results from the temporal and positional expression of genetic information during each cell cycle (for review, see Gober and Shapiro 1991). The predivisional cell is asymmetric in that it has a single flagellum at the incipient swarmer cell pole and a stalk-a polar extension of the cell membranes and cell wall-at the incipient stalked cell pole (Fig. 1). The biogenesis of both polar structures is temporally controlled, is an invariant part of each cell cycle, and is coordinated with other cell cycle events. Upon cell division, the progeny cells express different cellular functions; the sessile stalked cell initiates the replication of its chromosome, whereas the motile and chemotactically competent swarmer cell is unable to replicate its DNA. After approximately one-third of the complete cell cycle, the swarmer cell sheds its flagellum and initiates both DNA replication and stalk biosynthesis. Thereafter, the early genes involved in flagellar biosynthesis are expressed, initiating a regulatory hierarchy of flagellar genes that culminates in the de novo synthesis of a single flagellum at the pole opposite the stalk. The order of transcription initiation of the flagellar structural genes broadly reflects the order of assembly of their gene products into the flagellum. More than 40 genes are required for the biogenesis and function of the flagellum (Ely and Ely 1989). Evidence that many flagellar structural genes are transcribed from promoters requiring the alternative $\sigma$-fac- tor, $\sigma^{54}$, was provided by studies of wild-type and mutant flagellar promoters (Minnich and Newton 1987; Mullin et al. 1987; Mullin and Newton 1989; Dingwall et al. 1990; Gober et al. 1991; Gober and Shapiro 1992), in vitro transcription using Escherichia coli $\sigma^{54}$ (Ninfa et al. 1989), and in vivo transcription of $C$. crescentus genes in E. coli (Dingwall et al. 1990; Ramakrishnan and Newton 1990).

The $\sigma^{54}$-RNA polymerase holoenzyme recognizes the $-12-24$ promoters, defined by conserved GG and GC doublets at -24 and -12 nucleotides, respectively, from the start of transcription (Kustu et al. 1989; Thöny and Hennecke 1989|; but, by itself, it is unable to catalyze isomerization of the closed to the open transcriptional complex (for review, see Kustu et al. 1989, 1991). To do so, it requires the action of an activator protein bound to a transcriptional enhancer (Popham et al. 1989). It has been shown in several cases that the activation of the activator protein itself requires phosphorylation by a sensor protein. These sensor-modulator couples, called two component regulatory systems, respond to changes in the environment by transducing the information from an environmental signal to the transcriptional activation of specific genes (for review, see Albright et al. 1989a; Stock et al. 1989; Bourret et al. 1991). The flagellar structural genes of $C$. crescentus, however, appear to respond to internal cell cycle-dependent signals (Stove and Stanier 1962; Poindexter 1964; Shapiro 1985). Because $C$. 


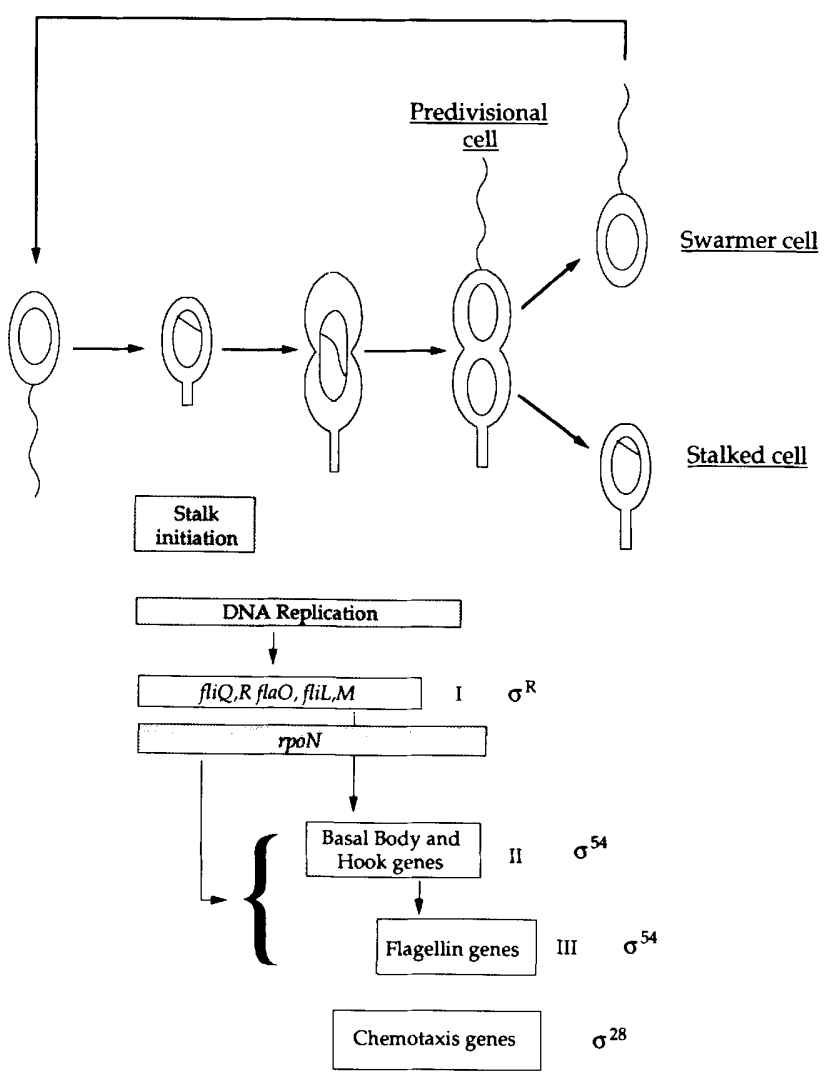

Figure 1. Schematic of the C. crescentus cell cycle and the regulatory hierarchy controlling flagellar biosynthesis. The swarmer cell contains a single polar flagellum, is motile and chemotactically competent, but is unable to initiate DNA replication. DNA replication initiates after differentiation of the swarmer cell into a stalked cell. As the stalked cell proceeds through the cell cycle, it elongates and expresses the early genes involved in flagellum biogenesis - the class I genes. These genes are expressed early in the cell cycle, their expression is sensitive to an interruption of DNA replication, their expression is essential for the transcription of the class II and class III genes, they have a conserved element in the promoter region and may require an unknown $\sigma$-factor for their transcription (termed $\sigma^{\mathrm{R}}$ ), and mutant alleles of these genes cause aberrant cell division. The class II genes encoding the hook and basal body proteins are expressed after the class I genes, and their expression is necessary for the expression of the class III genes (flagellins). The transcription of the genes from class II and class III requires the RNA polymerase $\sigma^{54}$ subunit. The different classes of flagellar genes are in open boxes.

crescentus utilizes the requirement of the $\sigma^{54}$-RNA polymerase holoenzyme for enhancer-binding activator proteins to regulate at least one temporally controlled event, flagellar biogenesis, it is reasonable that it might do so for other cell cycle-dependent events. In this paper we show that a rpoN disruption mutant is unable to synthesize either the flagellum or the stalk and exhibits an aberrant cell division phenotype. The transcription of $r p o N$ is temporally controlled in that it is induced at the swarmer-to-stalked cell transition. Thus, this alternative $\sigma$-factor responds to cell cycle cues and mediates the pleiotropic control of cell cycle events in C. crescentus.

\section{Results}

Isolation and identification of the $\mathrm{C}$. crescentus rpoN gene

The $C$. crescentus rpoN gene was cloned by the polymerase chain reaction (PCR), taking advantage of the fact that $r p o N$ homologs have been cloned from a variety of bacteria. The isolation of a 550-bp fragment of $C$. crescentus DNA containing internal sequences encoding conserved regions of the bacterial $\sigma^{54}$ protein is described in Materials and methods.

The 550-bp PCR fragment was used to screen a $C$. crescentus $\lambda$ ZAP chromosomal library. Four positive clones, pYB101, pYB102, pYB103, and pYB104, were used for further characterization. The 550-bp PCR fragment was also used to probe a $C$. crescentus cosmid library, and a rpoN-containing cosmid (pYB100, cosmid A11) was isolated. Subclones were used to sequence the $r p o N$ gene. Four open reading frames (ORFs; see Fig. 2) in $2.7 \mathrm{~kb}$ of DNA were identified as potential coding sequences by the CODONPREFERENCE program (Devereux et al. 1984) using third-position GC bias and a $C$. crescentus-derived codon usage table (Schoenlein et al. 1990). The sequence of the predicted product of the second of these ORFs is similar to that of $\sigma^{54}$ proteins from other bacteria (Fig. 3). The degree of homology ranges from $56 \%$ identity and $72 \%$ similarity with the $r p o N_{1}$ gene of Bradyrhizobium japonicum (Kullik et al. 1991) to $33 \%$ identity and $52 \%$ similarity with the rpoN gene of Bacillus subtilis (Débarbouille et al. 1991). The highly conserved rpoN box motif (van Slooten et al. 1990) at the carboxy-terminal region of rpoN genes is also conserved in C. crescentus (Fig. 3). The C. crescentus rpoN gene also has the pattern of sequence conservation observed in other rpoN genes: conserved amino- and carboxy-terminal domains separated by a highly divergent central domain.

The genetic organization around the $r p o N$ gene is also conserved in C. crescentus (see Fig. 2). Upstream of rpoN is an ORF homologous to the ORF1 of Rhizobium meliloti (Albright et al. 1989b), Thiobacillus ferrooxidans (Berger et al. 1990), Klebsiella pneumoniae (Merrick and Gibbins 1985), and Pseudomonas putida (Inouye et al. 1989|, which are similarly situated upstream of rpoN. Almost all bacteria have a conserved ORF directly downstream of rpoN as well (Merrick and Coppard 1989). In C. crescentus, this ORF (orf4) is also found downstream of $r p o N$, although it is separated from it by an additional ORF (orf3) of 203 codons (shown diagrammatically in Fig. 2).

The position of rpoN on the physical map of the $C$. crescentus chromosome was determined by hybridizing the 550-bp PCR fragment to a Southern blot of chromosomal DNA digested with AseI and DraI. These restriction enzymes yield 12 and 39 fragments of the chromosome, respectively (Ely and Ely 1989). The genetic map 
A

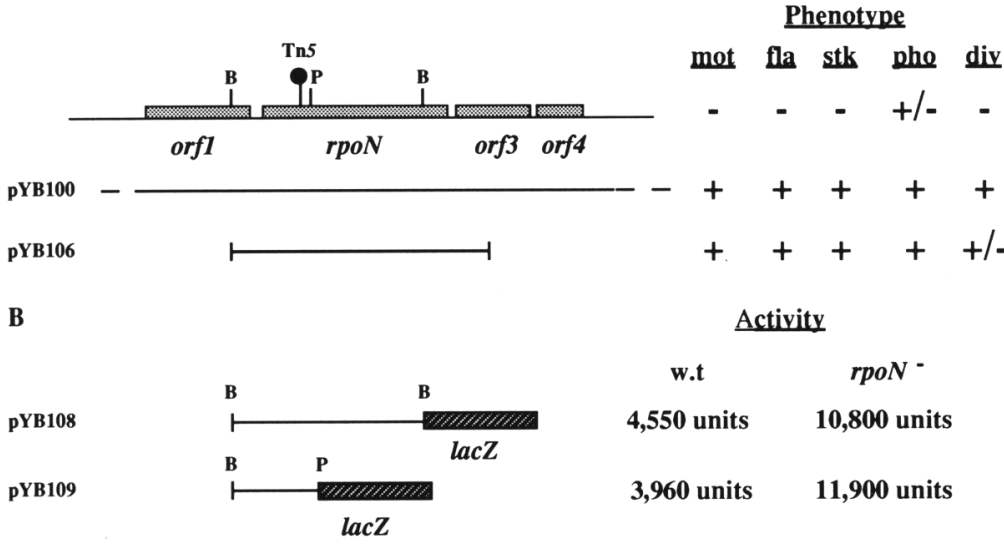

Figure 2. Complementation analysis and promoter probe fusions of rpoN. (A) Complementation phenotypes of a rpoN::Tn 5 mutant. The ORFs in the $r p o N$ region are indicated by stippled boxes. The Tn5 insertion in $r p o N$ is indicated. Light microscopy was used to determine motility (mot) and electron microscopy to identify flagella (fla), stalks (stk), and the ability to respond normally to phosphate limitation (pho) and normal cell division (div). (+) Wild-type phenotype; $(-)$ deficient phenotype; $(+/-)$ partially deficient phenotype. $(B)$ Promoter probe analysis of the rpoN gene. The $\beta$-galactosidase activity (in Miller units) conferred by plasmid-borne transcriptional fusions to $l a c Z$ was determined from four independent measurements. Fusions equivalent to pYB108 and pYB109 to $1 a c Z$ in the opposite orientation gave no detectable $\beta$-galactosidase activity over the background level from the vector alone (not shown). of the $C$. crescentus chromosome has been correlated to the physical map generated with these enzymes (Ely and Ely 1989). The PCR probe hybridized to a $250-\mathrm{kb}$ AseI and to a 305-kb DraI fragment (not shown). The 305-kb DraI fragment is difficult to resolve from the 310- and $320-\mathrm{kb}$ fragments, but it is the only DraI fragment of $\sim 300 \mathrm{~kb}$ that overlaps with the $250-\mathrm{kb}$ AseI fragment. The rpoN gene thus maps $\sim 100 \mathrm{~kb}$ to the left of the $C$. crescentus origin of DNA replication (Dingwall and Shapiro 1989; Marczynski and Shapiro 1992). This region includes the $f l b U$ gene, identified previously in a general Tn5 mutagenesis screen for nonmotile mutants (Ely and Ely 1989). Southern hybridization of chromosomal DNA digested with frequently cutting enzymes with the 550bp PCR fragment probe also indicated that this is the only copy of the rpoN gene in C. crescentus (not shown).

Because $f l b U$ is required for flagellum biosynthesis and a rpoN mutant is expected to be nonmotile, it was suspected that $f l b U$ is the $\sigma^{54}$ structural gene. Inverse PCR was thus used to determine whether the $\operatorname{Tn} 5$ in $f l b U$ of strain SC1055 was inserted in the rpoN gene (Fig. 4). SC1055 chromosomal DNA was digested to completion with PstI. The resulting fragments were ligated under conditions favoring intramolecular ligation. PCR was then performed using oligonucleotides L7 and R3. An amplified fragment of $\sim 700$ bp was obtained and was cut with PstI producing a 450-bp fragment (corresponding to the distance between the Tn5 PstI site and the L7 oligonucleotide) and a 250-bp fragment, containing DNA from the end of IS50R and from the bacterial chromosome (Fig. 4A). The 250-bp fragment was subcloned and sequenced. Figure 4B shows the sequence of this fragment containing the junction of IS50R in the Tn5 insert and chromosomal DNA. The DNA sequence upstream of the PstI site (from nucleotides 88 to 239) is identical to that of the rpoN-coding sequence between nucleotides 440 and 596 (Fig. 4B). Upstream of nucleotide 88, the sequence of the inverse PCR fragment is identical to that of the end of IS50R (Johnson and Reznikoff 1983). The first 20 nucleotides correspond to the sequence of the R3 oligonucleotide. These results indicate that the $\operatorname{Tn} 5$ of SC1055 has inserted between codons 146 and 147 of rpoN such that the right end of Tn5 points in the direction of rpoN transcription. The Tn5 mutation from SC1055 was transduced to the wild-type strains CB15 and NA1000, yielding strains SU213 and SU214, respectively, for subsequent characterization (Table 1).

\section{Expression of flagellar genes in the rpoN mutant}

Further evidence that the cloned and sequenced putative rpo $N$ gene encodes a functional $\sigma^{54}$ subunit was obtained by examining the expression of flagellar genes in the rpoN mutant background. Transcriptional fusions of the genes to a promoterless $l a c Z$ gene were constructed such that the coding regions were separated by stop codons in all three reading frames. These fusions were introduced into strain SU213 and assayed for $\beta$-galactosidase activity (Table 2). Transcription of the flagellar genes with known $\sigma^{54}$ promoters, flgF (Dingwall et al. 1992a), flbG, $f l a N, f l g L$, and $f \operatorname{lgK}$ (J.W. Gober, pers. comm.), was not detectable in the rpoN mutant. However, the transcription of two class I gene promoters, fliQR and fliLM, which share a unique promoter sequence (Dingwall et al. 1992b; Yu and Shapiro 1992), was increased twofold in SU213 relative to wild type (Table 2). This increase of transcription of class I genes in the rpoN mutant is similar to that seen in other class I mutant strains and is not exhibited by class II or class III fla mutants (see Fig. 1). The transcription of $r p o N$ is also increased two- to threefold in the rpoN::Tn5 mutant (Fig. 2). The level of transcription of a gene encoding a chemotaxis receptor protein, $m c p A$, predicted to use the $\sigma^{28}$ subunit (Alley et al. 19921, was comparable to that obtained in a wild-type background. We conclude that a Tn5 insertion in the $f l b U$ gene specifically prevents the transcription of flagellar genes that use a $\sigma^{54}$ promoter. This indicates that there is only one $\sigma^{54}$ gene in C. crescentus. The flbU gene will therefore be renamed rpoN as proposed by Thöny and Hennecke (1989). 


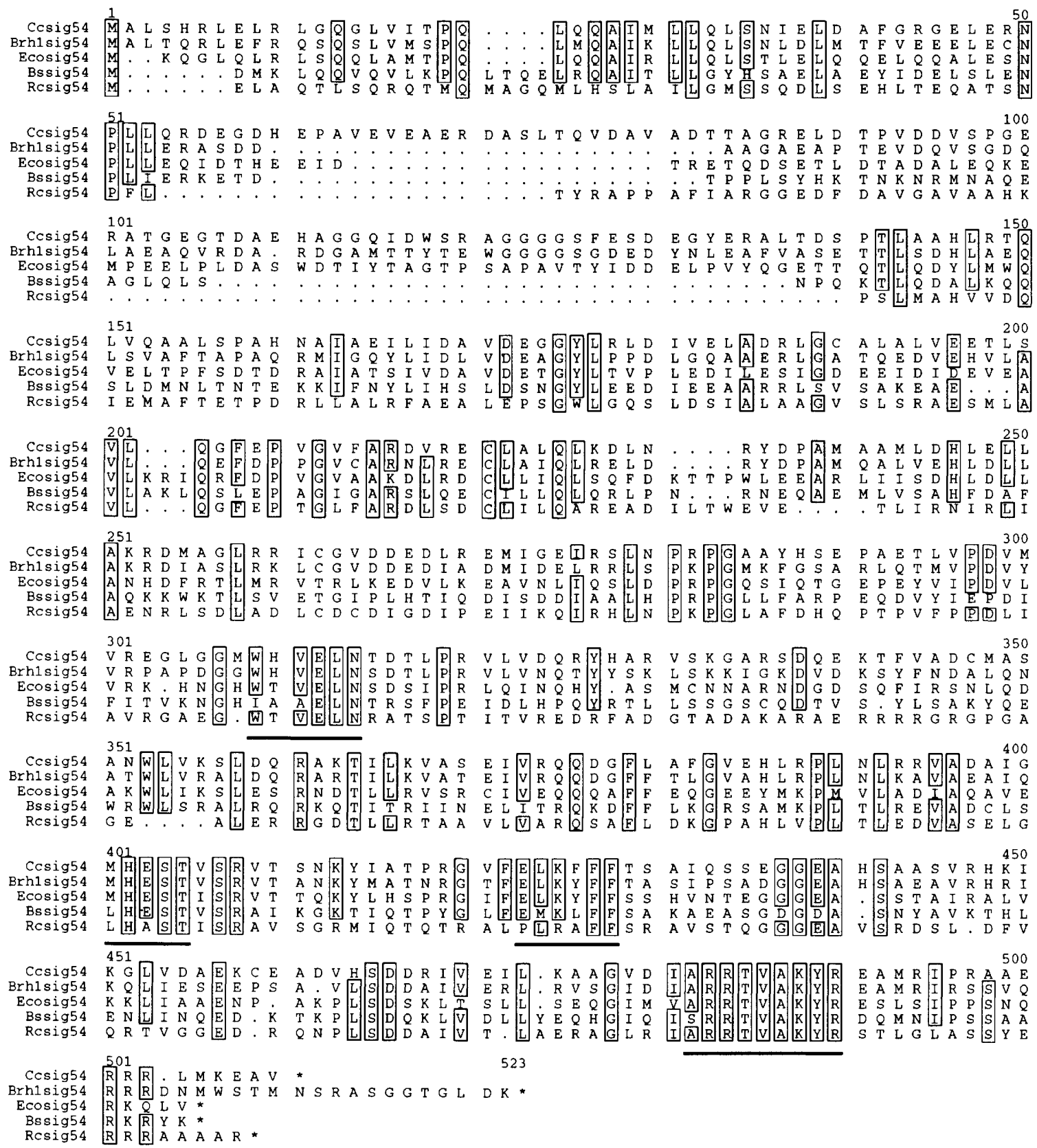

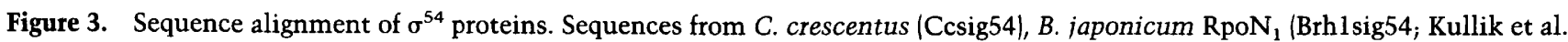
1991), E. coli (Ecosig54; Sasse-Dwight and Gralla 1990), B. subtilus (Bssig54; Débarbouille et al. 1991), and Rhodobacter capsulatus (Rcsig54; Jones and Haselkorn 1989) were aligned using the Pileup program. Identities between at least four out of five sequences are boxed. The highly conserved regions of homology targeted for PCR are indicated below the sequence alignments; the first (WLVELN) and the last ones (ARRTVAKYR) were used to amplify rpoN sequences from $C$. crescentus chromosomal DNA, and the two middle ones (MHEST and ELKYFF) were used to amplify sequences internal to the first PCR product. The GenBank accession number for the Caulobacter rpoN sequence is X68549.

\section{Polar defects and cell division phenotype of rpoN mutant strains}

It was reported previously that the flbU::Tn5 allele of rpoN in SC1055 was not motile (Ely and Ely 1989). Electron microscopy of strain SU213 carrying this rpoN mutant allele showed that cells lacked flagella (Fig. 5B), as expected from a strain that is unable to transcribe a large number of flagellar structural genes (Table 2). Surprisingly, these cells also lacked stalks (Fig. 5B). In a population of mutant cells, only 4 out of 1000 cells had a polar structure that could conclusively be identified as a stalk, whereas in a wild-type population, $\sim 75 \%$ of the cells in the total population have stalks (Table 3). Small blebs 
$\mathbf{A}$

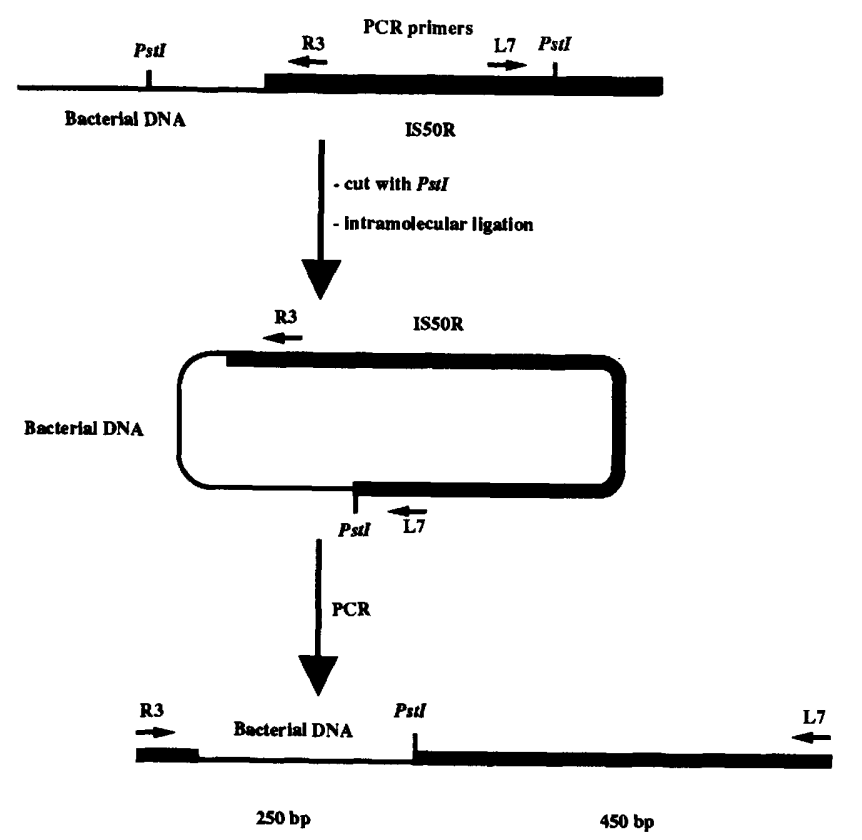

B

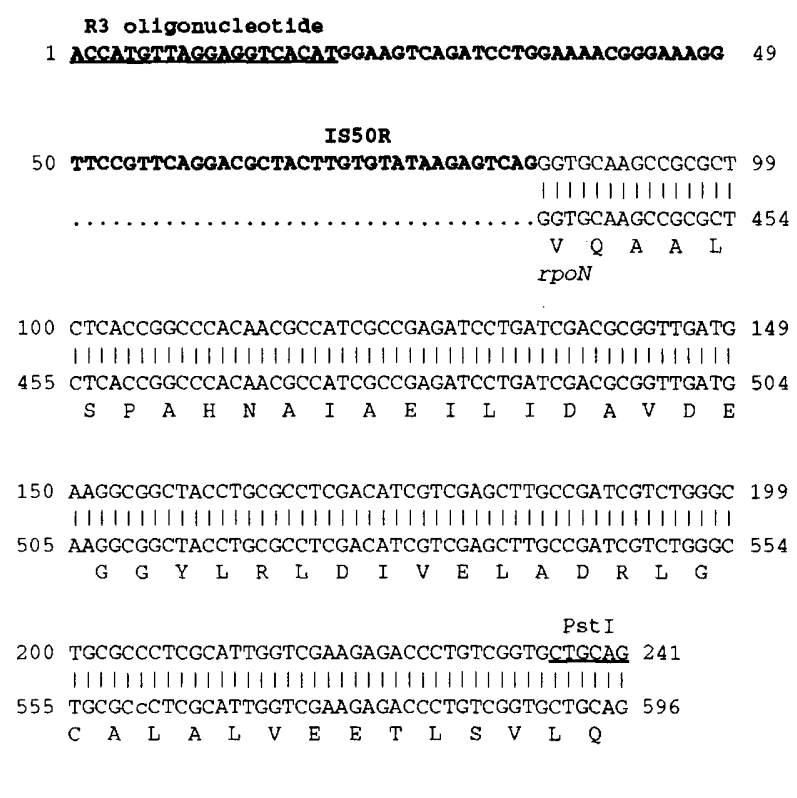

Figure 4. Inverse PCR of the Tn5 insertion in $f l b U .(A)$ Diagram of the inverse PCR procedure. A cartoon of chromosomal DNA in the region of the Tn 5 insertion is shown. The relative position and orientation of the oligonucleotides corresponding to sequences from the ends of Tn 5 is indicated by arrows (R3 and L7). Note that the oligonucleotide sequences are on the IS50R side of the Tn 5 PstI site. Chromosomal DNA from SU213 was isolated, digested with PstI, and subjected to intramolecular ligation. The resulting intramolecular ligation product containing Tn5 sequences has the oligonucleotide complementary sequences oriented such that oligonucleotides R3 and L7 are oriented toward the chromosomal DNA sequence. A PCR reaction of the mixture of ligation products yields amplified fragments containing Tn5 DNA and chromosomal DNA from the first chromosomal $P$ stI sites to the Tn 5 insertion site. $(B)$ Sequence of the inverse PCR product from the $f l b U:: T n 5$ insertion strain compared with the cloned rpoN gene. The sequence of the portion identical to IS50R is indicated in boldface type, and the sequence corresponding to the R3 oligonucleotide is underlined. The rest of the sequence is from $C$. crescentus chromosomal DNA and is compared with that of the cloned $C$. crescentus rpoN gene. The amino acid sequence of $\sigma^{54}$ encoded by this region is indicated under the DNA sequence of the rpoN gene.

can be seen at the pole of $\sim 2 \%$ of the mutant cells (Fig. $5 \mathrm{~B})$. Examination of these structures at high magnification showed that the blebs are probably composed of hold-fast material, normally seen at the tip of the stalk. This mutant strain also exhibits aberrant cell division (Figs. 2A and 5B). A significant proportion of cells $\{10 \%$; Table 3) were filamentous, whereas this happens very rarely $(<1 \%$; Table 3$)$ in a wild-type population. Many of these elongated cells have no discernible constriction site, and some have defects in the positioning of the constriction site, which is frequently positioned close to one pole in the mutant, as compared with the middle of the cell in wild-type populations. Finally, some cells have a constriction at more than one site. Thus, there seems to be a loss of the coordination of cell division in the rpoN disruption mutant.

\section{$\sigma^{54}$ is not necessary for nitrogen assimilation in C. crescentus}

$\sigma^{54}$ is known to be involved in numerous metabolic functions in other bacteria (Kustu et al. 1989). Accordingly, we tested the ability of $C$. crescentus wild-type and $r p o N^{-}$strains to grow in different media and to uti- lize various nitrogen sources. SU213 grows with a normal generation time (180 min) in $\mathrm{M} 2$ minimal medium and is thus prototrophic. Because $C$. crescentus is sensitive to some amino acids at high concentrations, we used a crystal plate assay (see Materials and methods; Ferber and Ely 1982) to test the ability of CB15 and SU213 to utilize different nitrogen sources /ammonium chloride, aspartic acid, glutamic acid, arginine, histidine, asparagine, glutamine, and lysine). Under these test conditions, ammonium chloride, aspartic acid, glutamic acid, and arginine are all good nitrogen sources for both strains; histidine and asparagine are used less efficiently by both strains, and glutamine, lysine, and urea cannot be used as nitrogen sources by either strain. The growth of strain SU213 is identical to CB15 with respect to nitrogen source utilization, suggesting that $\sigma^{54}$ is not involved in nitrogen assimilation in C. crescentus.

\section{Phosphate starvation stimulates stalk growth in the rpoN mutant}

Previous studies have shown that stalk length is increased dramatically when Caulobacter are starved for phosphate (Schmidt and Stanier 1966; Poindexter 1984). 
Table 1. Strains and plasmids used in this study

\begin{tabular}{|c|c|c|}
\hline Strain & Relevant genotype & Source or reference \\
\hline \multicolumn{3}{|l|}{ E. coli } \\
\hline S17-1 & E. coli $294:: \mathrm{RP} 4-2(\mathrm{Tc}:: \mathrm{Mu})(\mathrm{Km}:: \mathrm{Tn} 7)$ & Simon et al. $(1983)$ \\
\hline $\mathrm{DH} 5 \alpha$ & $\begin{array}{l}\phi 80 \mathrm{~d} l a c Z \Delta \mathrm{M} 15, \text { end } A 1, \text { rec } A 1, \text { hsdR } 17\left(\mathrm{r}^{-}, \mathrm{m}^{+}\right) \text {, supE } 44, \text { thi- } 1, \lambda^{-}, \\
\text {gyrA, relA1, }\end{array}$ & Hanahan (1985) \\
\hline \multicolumn{3}{|c|}{ C. crescentus } \\
\hline $\mathrm{CB} 15$ & wild-type & Poindexter (1964) \\
\hline NA1000 & previously called $\mathrm{CB} 15 \mathrm{~N}$, a synchronizable derivative of $\mathrm{CB} 15$ & Evinger and Agabian (1977) \\
\hline SC1055 & flbU(rpoN)::Tn5, proA, str140 & Ely and Ely (1989) \\
\hline SU213 & CB15, rpoN::Tn5 & this work \\
\hline SU214 & NA1000, rpoN::Tn5 & this work \\
\hline SU216 & NA1000, rpoN::pYB111 & this work \\
\hline Plasmid & Relevant characteristics or construction & Source or reference \\
\hline pYB 100 & cosmid A11, a pLAFR5-derived cosmid containing rpoN & this work \\
\hline pYB101 & $\begin{array}{l}\text { a plasmid rescued from a } \lambda Z A P \text { clone (pSK-derivative) containing } \\
\text { part of } r p o N\end{array}$ & this work \\
\hline pYBl02 & $\begin{array}{l}\text { a plasmid rescued from a } \lambda Z \mathrm{ZAP} \text { clone (pSK-derivative) containing } \\
\text { part of } r p o N\end{array}$ & this work \\
\hline pYB103 & $\begin{array}{l}\text { a plasmid rescued from a } \lambda Z A P \text { clone (pSK-derivative) containing } \\
\text { part of } r p o N\end{array}$ & this work \\
\hline pYB104 & $\begin{array}{l}\text { a plasmid rescued from a } \lambda \mathrm{ZAP} \text { clone (pSK-derivative) containing } \\
\text { part of } r p o N\end{array}$ & this work \\
\hline pYBl05 & $\begin{array}{l}\text { a derivative of } \mathrm{pYB} 101 \text { and } \mathrm{pYB} 107 \text { containing the complete } \\
\text { coding region of rpoN, its promoter, and approximately half of } \\
\text { the orf } 3 \text { gene }\end{array}$ & this work \\
\hline pYB106 & the $1.7-\mathrm{kb}$ BamHI fragment of pYB105 cloned into $\mathrm{placZ} / 290$ & this work \\
\hline pYB107 & $\begin{array}{l}\text { the } 1.7-\mathrm{kb} \text { BamHI fragment from pYB100 containing most of rpoN } \\
\text { in pSKII + with rpoN in the opposite orientation from lacZ }\end{array}$ & this work \\
\hline pYB108 & $\begin{array}{l}\text { the } 1.7-\mathrm{kb} \text { BamHI fragment from pYB100 containing most of rpoN } \\
\text { in placZ/290 in the same orientation as lacZ }\end{array}$ & this work \\
\hline pYB109 & $\begin{array}{l}\text { the } 0.3-\mathrm{kb} \text { BamHI-PstI fragment from pYBl00 containing the } \\
\text { beginning of } r p o N \text { in placZ/290 in the same orientation as } l a c Z\end{array}$ & this work \\
\hline pYB110 & $\begin{array}{l}\text { the } 1.7-\mathrm{kb} \text { BamHI fragment from pYB } 100 \text { containing most of rpoN } \\
\text { in pSKII + with rpoN in the same orientation as lacZ }\end{array}$ & this work \\
\hline pYB111 & $\begin{array}{l}\text { the } 1.7-\mathrm{kb} \text { BamHI fragment from pYBl00 containing most of } r p o N \\
\text { in pGSZ in the same orientation as } 1 a c Z\end{array}$ & this work \\
\hline pGSZ & a spec $^{\mathrm{R}}$ derivative of pGMTZ1 & Alley et al. (1991) \\
\hline $\mathrm{placZ} / 290$ & $1 a c Z$ transcriptional fusion vector, $\mathrm{Tet}^{\mathrm{R}}$, IncP-1 replicon, $\mathrm{mob}^{+}$ & $\begin{array}{l}\text { M.R.K. Alley and J.W. Gober } \\
\text { (unpubl.) }\end{array}$ \\
\hline $\begin{array}{l}\text { pSKII + } \\
\text { pSK - }\end{array}$ & $\begin{array}{l}\text { phagemid, } A m p^{R}, C o l E l \text { ori, } f 1|+| \text { ori } \\
\text { phagemid } A m p^{R}, C o l E l \text { ori } f 1 /-\mid \text { ori }\end{array}$ & Alting-Mees and Short (1989) \\
\hline & phagemid, Amp ${ }^{\mathrm{R}}$, Col El ori, $\mathrm{fl}|-|$ ori & Short et al. (1988) \\
\hline
\end{tabular}

To determine whether the inability of the rpoN mutant strain SU213 to form stalks due to the lack of enzymes involved in stalk biogenesis or the loss of cellular cues that signal the onset of stalk biogenesis, we tested the effect of phosphate limitation. Both wild-type (CB15) and mutant (SU213) cells were placed in minimal glucose medium containing different phosphate concentrations and were incubated at $30^{\circ} \mathrm{C}$ overnight with aeration. Cultures of CB15 grown in medium containing $20 \mu \mathrm{M}$ phosphate have many cells with stalks that are $\sim 10$ times as long as those grown in rich medium (Fig. 5C). Even though stalks fail to form in strain SU213 grown in rich medium (Fig. 5B), growth in low phosphate results in stalk formation (Fig. 5D). However, even under these conditions, stalk elongation never proceeds to the extent of that observed in wild-type cells grown in rich medium (cf. with Fig. 5A). This indicates that the enzymes and factors required for stalk biogenesis are synthesized to a certain extent in an $r p o N$ mutant under conditions of phosphate limitation but that the requirement for $\sigma^{54}$ for stalk biogenesis is only partially relieved under these growth conditions.

The rpoN ::Tn5 phenotype is due solely to disruption of rpoN

It was possible that the complex phenotype of the rpoN::Tn5 mutant was, in part, the result of polar effects of the Tn5 insertion on the genes downstream from rpoN. To test this possibility, we attempted to complement the complex phenotype of strain SU213 using a subclone, pYB106, which includes $300 \mathrm{bp}$ upstream of $r p o N$, the complete coding region, and 350 bp downstream (coding for 100 amino acids out of the 203 of 
Table 2. Transcription of flagellar genes in a rpoN mutant

\begin{tabular}{|c|c|c|c|c|}
\hline \multirow{2}{*}{$\begin{array}{l}\text { Flagellar promoter } \\
\text { fused to } l a c Z\end{array}$} & \multirow[b]{2}{*}{ Reference } & \multirow{2}{*}{$\begin{array}{l}\text { Promoter } \\
\text { type }\end{array}$} & \multicolumn{2}{|c|}{$\begin{array}{c}\beta \text {-Galactosidase } \\
\text { activity }^{\mathrm{a}}\end{array}$} \\
\hline & & & $\mathrm{CB} 15$ & SU213 \\
\hline$f l b G$ & Gober et al. (1991) & $\sigma^{54}$ & 2200 & 70 \\
\hline flaN & Gober and Shapiro (1992) & $\sigma^{54}$ & 520 & 20 \\
\hline$f \lg F$ & Dingwall et al. (1992a) & $\sigma^{54}$ & 1790 & 40 \\
\hline fliL & Yu and Shapiro (1992) & $\sigma^{\mathrm{R}}$ & 2750 & 5610 \\
\hline fliQ & Dingwall et al. $\{1992 b\}$ & $\sigma^{R}$ & 1250 & 2100 \\
\hline$m c p A$ & M.R.K. Alley (unpubl.) & $\sigma^{28}$ & 750 & 920 \\
\hline
\end{tabular}

${ }^{a}$ Transcription was determined by measuring the $\beta$-galactosidase activity conferred by plasmid-borne transcriptional fusions of the different genes to $l a c Z$.

ORF3|. This strain was tested for motility, the presence of flagella and stalks, the ability to normally stimulate stalk length when limited for phosphate, and normal cell division (Fig. 2A). Strain SU213 containing pYB106 is motile, has both flagella and stalks, and, like wild type, synthesizes long stalks under conditions of phosphate limitation. Less than $1 \%$ of the cells in the complemented mutant culture are filamentous. However, the presence of pYB106 in SU213 causes the appearance of morphological aberrations (not shown) in a small proportion of the population (1-5\%). This could be the result of an increased copy number of $r p o N$ (two to four copies per cell), to the inability of pYB106 to complement a possible polar effect of the Tn5 on genes downstream from rpoN, or to the expression of a truncated orf3 product from the plasmid. The complementing cosmid pYB100, which contains $>20 \mathrm{~kb}$ of $C$. crescentus DNA with at least $1.6 \mathrm{~kb}$ of DNA upstream of rpoN and at least $1.4 \mathrm{~kb}$ downstream, restores a complete wild-type phenotype to strain SU213. The complementation of all of the phenotypes of SU213 by pYB106 indicates that they are due solely to disruption of $r p o N$ and not to a polar effect on genes downstream. These results also indicate that the rpoN promoter is contained within the $300 \mathrm{bp}$ upstream of rpoN. To confirm this, we constructed transcriptional fusions of rpoN DNA to a promoterless $l a c Z$ gene on a plasmid. In a wild-type background, both the BamHI fusion in pYB108 and the BamHI-PstI fusion in pYB109 yielded $\sim 4000$ units of $\beta$-galactosidase activity, confirming the presence of a promoter within the $300 \mathrm{bp}$ of DNA upstream of $r p o N$ (Fig. 2B). As discussed earlier, in the rpoN mutant background, there is a two- to threefold increase of $\beta$-galactosidase activity relative to wild type for both fusions.

\section{Temporal control of rpoN expression}

The transcription of $r p o N$ as a function of the cell cycle was studied using a rpoN-lacZ transcriptional fusion integrated at the rpoN locus of the C. crescentus chromosome. The rpoN-lacZ integration strain, SU216, was constructed such that the lacZ gene was placed under the control of the $r p o N$ transcriptional regulatory elements (Fig. 6A). At the same time, this integration recreates a complete copy of the rpoN gene under the con- trol of the rpoN proximal regulatory elements (Fig. 6A). This regulatory region contains the cis-acting elements necessary for complementation of the rpoN::Tn 5 mutant when present with the $r p o N$-coding region on a plasmid (Fig. 2A) and contains the rpoN promoter as shown using transcriptional fusions (Fig. 2B). The integration strain is indistinguishable from the wild-type CB15 strain as assayed for swimming, flagella and stalk morphology, and cell division. Furthermore, this strain proceeds normally through the cell cycle, as determined by microscopic examination of synchronized cultures.

To test rpoN transcription in synchronized cultures, swarmer cells were isolated from strain SU216 and allowed to proceed through the cell cycle. At 15-min intervals, culture samples were removed and pulse labeled with $\left[{ }^{35} \mathrm{~S}\right] \mathrm{methionine}$ for $5 \mathrm{~min}$, after which the cells were collected by centrifugation. Figure $6 \mathrm{~B}$ shows the result of immunoprecipitation of cell extracts with anti$\beta$-galactosidase antibody. Also shown is the control using anti-flagellin antibodies for each time point. The timing of flagellin expression is identical to wild type, confirming that the cells of strain SU216 proceed normally through the cell cycle. The high level of expression of the $25-\mathrm{kD}$ flagellin in swarmer cells is the result of the continued translation of $f l g K$ mRNA in the swarmer cell (Milhausen and Agabian 1983). The expression of $\beta$-galactosidase, which reflects the transcription of the rpoN-lacZ fusion, is temporally controlled. The level of $\beta$-galactosidase is low early in the cell cycle, rises $\sim 10$ - fold starting between 0.3 and 0.4 cell division units, and is maximal between 0.7 and 0.8 division units, after which it decreases. Microscopic examination of cells in the synchronized culture indicates that stalk initiation occurs at approximately one-third of the cell cycle (not shown|. Figure 6, B and C, shows that rpoN transcription is stimulated earlier in the cell cycle than flagellin gene expression. This experiment reveals that rpoN transcription is initiated relatively early in the cell cycle, and its maximal level of transcription coincides with the peak of $\sigma^{54}$-dependent gene expression.

\section{Discussion}

The complex series of events that are required for Caulobacter differentiation are subject to both temporal and 

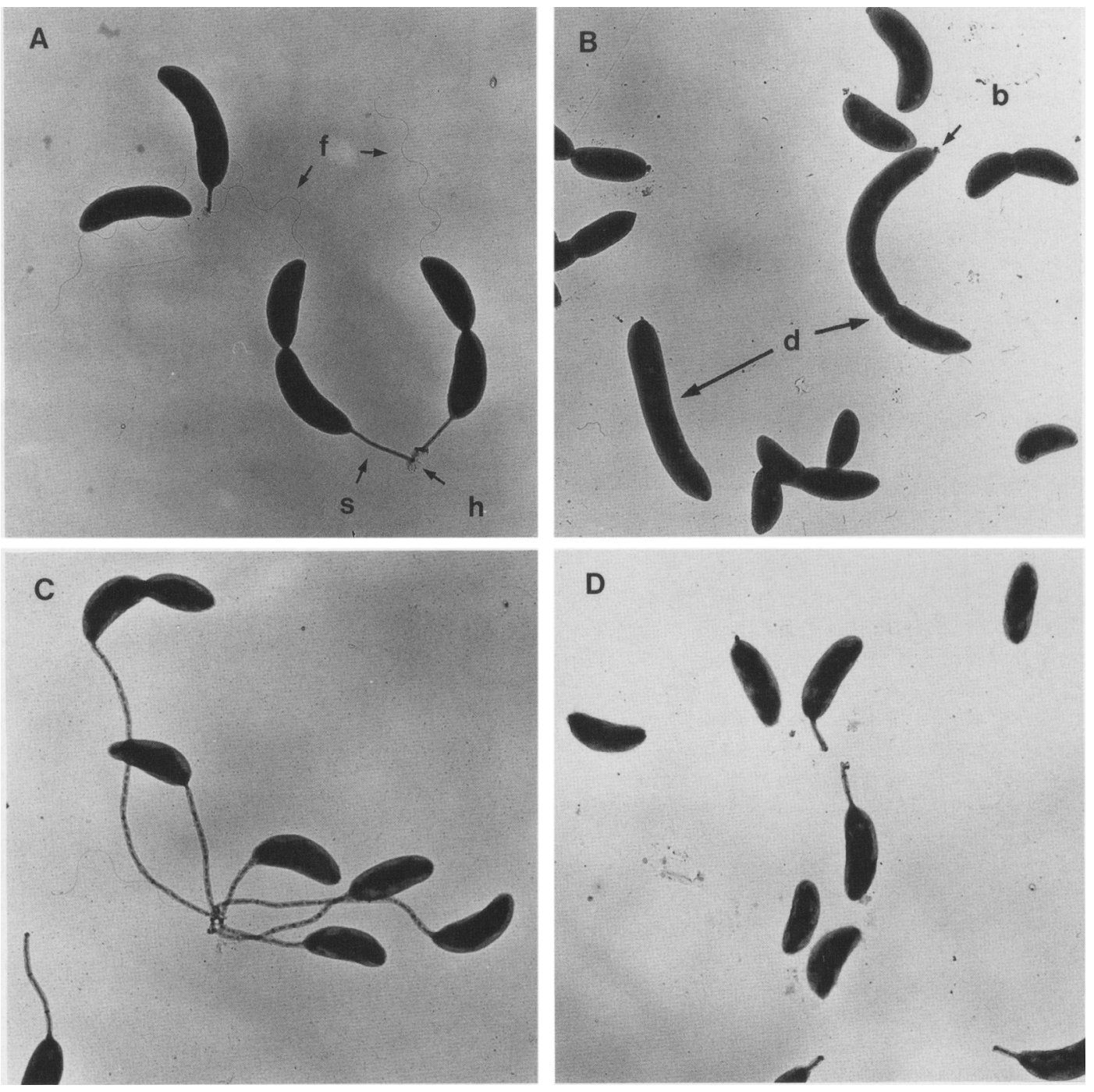

Figure 5. Phenotype of a rpoN insertion mutant. $(A)$ Wild-type $C$. crescentus (CB15) grown in PYE medium; $(B)$ a rpoN mutant (SU213) grown in PYE medium; $(C)$ wild-type C. crescentus (CB15) grown in PIG medium containing $20 \mu \mathrm{M}$ phosphate; $(D)$ a rpoN mutant (SU213) grown in PIG medium containing $20 \mu \mathrm{M}$ phosphate. Arrows indicate flagella (f), stalks (s), hold-fast (h), blebs (b), and abnormally dividing cells $(\mathrm{d})$.

spatial control. The hallmark events of this differentiation process are the biosynthesis of two external polar structures, the flagellum and the stalk. Their de novo biogenesis at the cell poles results from the asymmetry expressed in the predivisional cell. The flagellum is assembled at the pole opposite the existing stalk in the predivisional cell. Cell division yields a swarmer cell and a stalked cell. After approximately one-third of the cell cycle, the swarmer flagellum is shed, chemotaxis proteins are degraded (M.R.K. Alley, J.R. Maddock, and L. Shapiro, in prep.), DNA synthesis is initiated, and a new stalk is formed at the site of flagellar release. This is also the time when the transcription of the early genes required for flagellum biosynthesis, the class I genes, is stimulated (see Fig. 1). Subsequent to the induction of the class I genes, the transcription of the
Table 3. Morphology of C. crescentus wild-type and $\mathrm{rpoN}^{-}$cells

\begin{tabular}{lcc}
\hline Cell type & $\begin{array}{l}\text { CB15 } \\
\text { (wild type) } \\
\langle \%\rangle\end{array}$ & $\begin{array}{l}\text { SU213 } \\
\langle\text { rpoN }\end{array}$ \\
\hline Swarmers & $25^{\mathrm{a}}$ & $\begin{array}{l}(\%) \\
\text { Cells containing stalks }\end{array}$ \\
Cell division defects $^{\mathrm{d}}$ & $75^{\mathrm{a}}$ & $0^{\mathrm{b}}$ \\
\hline
\end{tabular}

\footnotetext{
${ }^{\mathrm{a}} \mathrm{Tax}(1978)$.

brom 1000 cells examined by electron microscopy.

'This includes both stalked cells and predivisional cells containing a stalk.

${ }^{\mathrm{d}}$ Cell division defects are defined as cells that are longer than $1 \frac{1}{2}$ average length predivisional cell and/or cells that have more than one constriction site.

${ }^{\text {eFrom }} 2000$ cells examined by electron microscopy.
} 
A

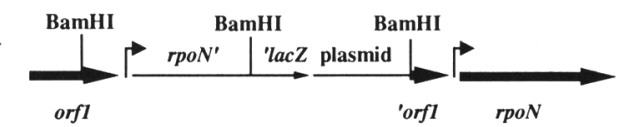

B

$\begin{array}{llllllllllll}\text { minutes } & 0 & 15 & 30 & 45 & 60 & 75 & 90 & 105 & 120 & 135 & 150\end{array}$
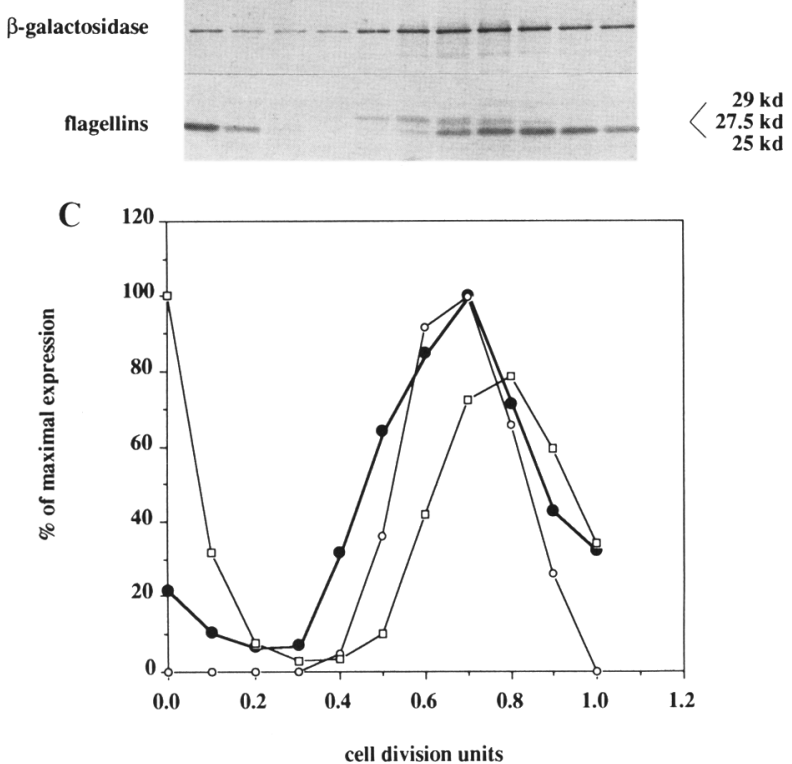

Figure 6. Cell cycle expression of rpoN. (A) Diagram of the integrated rpoN-lacZ transcriptional fusion in SU216 used to assay rpoN transcription. Integration of this fusion in the chromosome restores a wild-type $r p o N$ gene downstream of its promoter in strain SU216. The thin lines represent the rpoN-lacZ fusion and plasmid sequences; the bent arrows indicate the position of the $r p o N$ promoter. (B) Immunoprecipitation of $\beta$-galactosidase and flagellin proteins from strain SU216 through the cell cycle (see Materials and methods). The antiflagellin antibody immunoprecipitates the 25-, 27.5-, and 29-kD flagellins. (C) Graph of temporal transcription of rpoN (O) and expression of the $\sigma^{54}$-dependent flagellin genes flgL $(27.5 \mathrm{kD})(O)$ and $f l g K$ $(25 \mathrm{kD})(\square)$. The autoradiograph shown in $B$ was scanned, and the intensity of the bands was plotted as the percentage of the maximal intensity for the band corresponding to each protein. One cell division unit is the time required for cell division starting from swarmer cells, as judged by light microscopy, i.e., $150 \mathrm{~min}$.

class II and class III genes, encoding mostly $\sigma^{54}$-dependent flagellar structural proteins, is activated. Thus, the biosynthesis of both the flagellum and the stalk is developmentally regulated as a function of the cell cycle. We have shown here that the $\sigma^{54}-$ RNA polymerase subunit is required for the de novo biogenesis of both of these polar structures. The transcription of the rpoN gene is strongly stimulated at the swarmer-to-stalked cell transition coincident with the onset of stalk formation and prior to the transcription of $\sigma^{54}$-dependent flagellar genes encoding the structural components of the flagellum.

\section{In vivo requirement of $\sigma^{54}$ for flagellar biosynthesis}

The absence of transcription of class II and class III flagellar genes in a rpoN disruption mutant demonstrates the in vivo requirement of $\sigma^{54}$ for flagellar biosynthesis. Combined with previous analyses of flagellar $-12,-24$ promoters, these results clearly show that transcription of flagellar structural genes is accomplished by $\sigma^{54}$-RNA polymerase holoenzyme in vivo. In bacteria in general, the activation of the enhancer-binding proteins of $\sigma^{54}$-dependent promoters responds to environmental signals (for review, see Albright et al. 1989a; Stock et al. 1989; Bourret et al. 1991). In contrast, the ordered series of events leading to differentiated cells in Caulobacter appears to depend on cell cycle signals rather than on environmental signals.

In the $C$. crescentus flagellar regulatory hierarchy, the expression of the class I genes, which are expressed relatively early in the cell cycle, is required for the expression of the class II and class III structural genes (Fig. 1). Class I includes at least seven genes. The flaO $(f l i F)$ gene appears to encode the first ring protein to be assembledthe M-ring (G. Ramakrishnan, J.-L. Zhao, and A. Newton, pers. comm.). Its operon includes the $n t r C$ homolog $f l b D$ which, in epistasis experiments, was shown to be required for transcription of the $f l b G$ promoter (Ramakrishnan and Newton 1990). The fliL and fliM genes encode proteins thought to interface with the flagellar motor; fliM is a homolog of a Salmonella typhimurium switch protein (Yu and Shapiro 1992). The fliQ and fliR genes (W. Zhuang and L. Shapiro, in prep.) and the $f l b F$ gene (Ramakrishnan et al. 1991; Sanders et al. 1992) encode putative membrane-associated proteins. Mutations in the class I genes result in an aberrant cell division phenotype, and the expression of three class I operons ( $f l i Q R$, fliLM, and flaO $f l b D)$ is sensitive to an interruption in DNA replication (Dingwall et al. 1992b; K. Quon, unpubl.). The $r p o N$ gene is similar to the class I flagellar genes in that it is expressed early in the cell cycle, a rpoN disruption mutant exhibits a cell division phenotype, and it is required for transcription of class II and class III flagellar genes. It is not known whether the expression of rpoN is sensitive to an interruption in DNA replication, as is the case for the class I flagellar genes. It is clear that the expression of rpoN does not depend on class I genes because class I gene mutants are able to make normal stalks (Dingwall et al. 1992b; Yu and Shapiro 1992), whereas the rpoN mutant is unable to do so. Because rpoN is not required for class I gene expression (Table 2), rpoN and class I genes may act at the same level of the flagellar regulatory cascade. Thus, the cell division phenotype exhibited by rpoN and class I gene mutants could be the result of a global regulatory mechanism coordinating early events in flagellar biogenesis to cell division.

\section{$\sigma^{54}$ is required for cell cycle-dependent stalk biosynthesis}

The biosynthesis of the stalk is a cell-surface growth precisely localized in space and time. Its appearance at the pole of the cell marks the transformation of a motile and chemotactically competent swarmer cell to a sessile stalked cell that is competent for the initiation of DNA 
replication. Observations of individual cells in microculture have revealed that stalk formation is an obligatory stage in the development of every swarmer cell (Stove and Stanier 1962). Nothing is known about the temporal and spatial signals that specify stalk biosynthesis. Stalk biosynthesis proceeds in two phases: initiation, which is restricted to the swarmer-to-stalked cell transition, and elongation, which occurs during the rest of the cell cycle and can be affected by environmental conditions, such as phosphate limitation (Schmidt and Stanier 1966; Poindexter 1984). Stalk biogenesis during the swarmer-to-stalked cell transition does not seem to depend on the initiation of DNA replication because synchronized swarmer cells of mutants affected in initiation of DNA replication can differentiate into stalked cells at the nonpermissive temperature (Osley and Newton 1977; Mansour and Shapiro 1981).

Within the confines of the operational definition of stalk initiation and stalk elongation, a rpoN disruption mutant of $C$. crescentus fails to initiate or elongate stalks under normal growth conditions. However, phosphate limitation appears to partially bypass the need for $\sigma^{54}$ for stalk biogenesis. Efficient stalk elongation, even under conditions of phosphate limitation, still appears to be dependent on rpoN gene expression. It has been shown that the expression of a Pseudomonas aeruginosa phosphate starvation-inducible porin is increased in $C$. crescentus in response to phosphate limitation (Walker et al. 1991). Because the gene encoding this phosphate starvation-inducible porin contains the promoter regulatory sequences enabling it to be regulated by the phosphate regulon in $P$. aeruginosa, these results suggest that C. crescentus also possesses a similar phosphate regulon. In $E$. coli and in $P$. aeruginosa, the phosphate regulon is independent of $\sigma^{54}$ (Wanner 1987; Filloux et al. 1988; Anba et al. 1990; Rao and Torriani 1990). This also appears to be the case in $C$. crescentus. The ability of the rpoN disruption mutant to make small stalks in response to phosphate limitation could be the result of the ability of the phosphate regulon to induce a set of signals that stimulate stalk biosynthesis in the absence of $\sigma^{54}$. This predicts that a double $r p o N$, pho mutant would be unable to synthesize stalks under conditions of phosphate limitation. We are trying to obtain mutants in the phosphate regulon to test this hypothesis.

The phenotype of the rpoN disruption mutant suggests that the cell cycle-dependent biosynthesis of stalks could be modulated by $\sigma^{54}$ and its enhancer-binding proteins as is the case for flagellar biosynthesis. In this case, it is clear that stalk biosynthesis cannot be solely dependent on $\sigma^{54}$ promoters. The simplest model assumes that essential stalk biosynthesis genes are not transcribed by $\sigma^{54}$-RNA polymerase holoenzyme but that $\sigma^{54}$ is required for a signal essential for stalk biosynthesis under normal conditions. Stalkless or stalk elongation mutants of C. crescentus have been identified previously (Schmidt 1968, 1969; Marino et al. 1976; Fukuda et al. 1977; Ely et al. 1984; Sommer and Newton 1989|, but all of them are able to synthesize flagella. The rpoN mutant also differs from the stalkless ple mutants that were iso- lated on the basis of their resistance to DNA phage $\phi \mathrm{CbK}$ infection (Fukuda et al. 1977; Ely et al. 1984; Sommer and Newton 1989), because we have shown that a rpoN::Tn5 disruption mutant is still sensitive to $\phi \mathrm{CbK}$ infection. Thus, the rpoN mutant is the first $C$. crescentus mutant deficient in the biosynthesis of the stalk and the flagellum.

\section{$\sigma$-factors and the control of differentiation}

There are numerous examples of sets of bacterial genes that are only expressed during periods of major change in cell physiology as a result of the expression of an alternative $\sigma$-factor required for the recognition of their promoter (Kustu et al. 1991). Changes in cell physiology can also induce a series of developmental events as in the case of the $B$. subtilis response to nutrient starvation (Losick and Stragier 1992). Sporulation of B. subtilis, which results in the formation of a spore inside the mother cell, is controlled by the successive appearance of four $\sigma$-factors. The activity of these $\sigma$-factors is coordinated between the forespore and the mother cell by a crisscross regulation that allows the two differentiating cells to communicate in order to coordinate the cellular events required for their morphogenesis.

We have shown that the transcription of $r p o N$ is restricted to a specific period of the cell cycle and that it is required for stalk biosynthesis, normal cell division, and the transcription of class II and class III flagellar genes. These results suggest that $\sigma^{54}$ could mediate the global timing of the central events of the $C$. crescentus cell cycle. The use of this minor $\sigma$-factor, which requires activator proteins for transcription initiation, allows refined control of the expression of individual or small groups of genes required for specific events in flagellar biosynthesis. The use of enhancer-binding transcriptional activators may prevent the synthesis of flagellar components that cannot be used. The combination of the $\sigma^{54}$ subunit and its cognate activator proteins ensures that flagellar biosynthesis only takes place during the proper window of the cell cycle. This could also be the case for the initiation of stalk biosynthesis. The coordination of the flagellar hierarchy and other cell cycle events may ensure that the unique spatial and temporal program of $C$. crescentus differentiation is properly executed. In $C$. crescentus, the use of a temporally controlled minor $\sigma$-factor in addition to a set of different transcriptional activators for the transcription of specific $\sigma^{54}$-dependent genes provides a precise modulation of transcription initiation in the control of complex developmental events.

\section{Materials and methods}

\section{Materials}

Oligonucleotides WLVELN (GAATTCTGGCTGGT/C,G)GAGCTGAAC), ARRTVAKYR (CG(A,G)TA(T,C)TTIGCIACIGTICGICGIGC), ELKYFF (GA(G,A)CT(G,C)AA(G,A)TA(T,C)TT$(\mathrm{T}, \mathrm{C}) \mathrm{TT})$, MHEST (ATGCA $(\mathrm{C}, \mathrm{T}) \mathrm{GA}(\mathrm{G}, \mathrm{A})(\mathrm{T}, \mathrm{A})(\mathrm{C}, \mathrm{G})(\mathrm{C}, \mathrm{G}) \mathrm{AC})$, R3 (ACCATGTTAGGAGGTCACAT), and L7 (CCATCTCAT- 
CAGAGGGTAGT) were obtained from Operon Technologies or from the PAN facility of Stanford University. Restriction endonucleases were from Boehringer Mannheim, New England Biolabs, or Bethesda Research Laboratories. EcoRI methylase was from New England Biolabs; T4 polynucleotide kinase, Klenow fragment of DNA polymerase, and T4 DNA ligase were from Boehringer Mannheim. Radionucleotides $\left[\alpha^{-32} \mathrm{P}\right] \mathrm{dGTP}$ and $\left[\alpha{ }^{35} S\right]$ dATP were from Amersham, and ${ }^{35}$ S $]$ methionine Translabel was obtained from Amersham. Antibiotics were from Sigma.

\section{Bacterial strains, plasmids, and growth conditions}

Bacterial strains and plasmids used in this study are described in Table 1. Strain SU216 used in the analysis of the temporal expression of rpoN was constructed as follows. The BamHI fragment containing most of the $r p o N$-coding region was subcloned from $\mathrm{pYB} 107$ into $\mathrm{pGSZ}$ such that the orientation of $r p o N$ was the same as that of $l a c Z$, giving rise to plasmid pYB111. This construction places lacZ under the control of the transcriptional regulatory elements of rpoN, but translation between both genes is uncoupled by the presence of translation stop codons in the three reading frames. Plasmid pYB111 was transformed into strain S17-1 and then conjugated into NA1000. This plasmid does not replicate in Caulobacter, and selection for gentamycin-resistant colonies was used to select for integration into the chromosome by homologous recombination. Because this plasmid contains the rpoN promoter, the $r p o N$ gene (or operon) is not disrupted by the integration. The structure of the integration was verified by Southern hybridization (not shown).

C. crescentus was grown at $30^{\circ} \mathrm{C}$ in PYE medium (Poindexter 1964), in minimal M2-glucose medium (Johnson and Ely 1977), or in PIG medium (Schoenlein et al. 1990). To test the effect of phosphate limitation on stalk biosynthesis, strains CB15 and SU213 were grown in medium containing excess phosphate 4 $\mathrm{mm})$. The cells were collected by centrifugation, and the cell pellet was resuspended in medium without phosphate. The cells were then diluted in medium containing different phosphate concentrations and were incubated at $30^{\circ} \mathrm{C}$ overnight with aeration. Ampicillin was used at $20 \mu \mathrm{g} / \mathrm{ml}$, kanamycin at $50 \mu \mathrm{g} / \mathrm{ml}$, tetracyclin at $2 \mu \mathrm{g} / \mathrm{ml}$, gentamycin at $5 \mu \mathrm{g} / \mathrm{ml}$, and spectinomycin at $100 \mu \mathrm{g} / \mathrm{ml}$. Cultures were synchronized by centrifugation in a Ludox gradient using a modification (Dingwall et al. 1990) of the procedure of Evinger and Agabian (1977). Swarmer cells (>95\% pure) were examined by light microscopy, which was also used to monitor the synchrony.

\section{Assay of nitrogen source utilization}

Assays were done essentially as described by Ferber and Ely (1982). CB15 and SU213 were grown in M2 minimal medium containing glucose as a carbon source and ammonium chloride as a nitrogen source, cells were harvested by centrifugation, and the cell pellet was resuspended in M2 minimal medium containing no nitrogen source. The cells were then spread on M2 minimal plates in the absence of a nitrogen source. After the liquid had adsorbed, crystals of different nitrogen sources were placed in the center of each plate and the plates were incubated at $30^{\circ} \mathrm{C}$. The plates were scored for cell growth after 2 days. Ability to utilize a nitrogen source was scored positive when a halo of dense cell growth appeared over a thin lawn of cell growth owing to the residual pools of nitrogen of the plated cells. This halo is the result of the diffusion of the nitrogen source through the agar, establishing a gradient of concentra- tion. Growth was thus observed in the zone of optimal nitrogen source concentration.

\section{Cell cycle transcription assays}

The time of transcription of rpoN and flagellin genes was assayed by immunoprecipitation of cultures pulse-labeled with ${ }^{35}$ S $]$ methionine. Swarmer cells were collected and allowed to proceed through the cell cycle in M2-glucose medium at $30^{\circ} \mathrm{C}$. Aliquots $(2 \mathrm{ml})$ of cells were removed at various stages of the cell cycle and pulsed-labeled for $5 \mathrm{~min}$ at $30^{\circ} \mathrm{C}$ with $15 \mu \mathrm{Ci}$ of $\left.{ }^{35} \mathrm{~S}\right]$ methionine. The cells were collected by centrifugation and washed once with M2 medium, and the pellets were frozen. Immunoprecipitations were done on samples containing the same amount of radioactivity, essentially as described by Gomes and Shapiro (1984).

\section{General DNA manipulations}

General cloning procedures were as described (Ausubel et al. 1989; Sambrook et al. 1989). DNA sequencing was done using either double-stranded templates (Brun et al. 1991) or singlestranded templates prepared from Bluescript phagemids by the dideoxynucleotide chain-termination method (Sanger et al. 1977) using the Sequenase kit from U.S. Biochemical. Part of the sequencing was done at the PAN facility of Stanford University using Taq cycle sequencing with fluorescently labeled dye primers or dye dideoxynucleotides using kits from Applied Biosystems and the 373A DNA Sequencer from the same company. The DNA sequence was analyzed using the GCG package of the University of Wisconsin (Devereux et al. 1984). The codon usage table used for the GC bias analysis was generously provided by Bert Ely (Schoenlein et al. 1990).

\section{Amplification of a DNA fragment containing part of the $\mathrm{C}$. crescentus rpoN gene}

PCR was used to amplify rpoN sequences from $C$. crescentus chromosomal DNA. Degenerate oligonucleotides representing the predicted coding sequence for highly conserved amino acid sequence motifs of $\sigma^{54}$ proteins were synthesized according to the $C$. crescentus codon usage (Schoenlein et al. 1990). These motifs include the so-called rpoN box (van Slooten et al. 1990), which is invariant in the carboxyl terminus of $\sigma^{54}$ proteins, and three other highly conserved motifs in the carboxy-terminal domain of homology (see Fig. 3). Oligonucleotides encoding WLVELN and ARRTVAKYR were used to amplify genomic sequences from total C. crescentus chromosomal DNA with PCR. Reactions were done in $100 \mu \mathrm{l}$ of reaction buffer containing 100 pmoles of each oligonucleotide (WLVELN and ARRTVAKYR ), $140 \mathrm{ng}$ of $C$. crescentus chromosomal DNA /sonicated to an approximate average size of $2 \mathrm{~kb}$ ), $10 \mathrm{~mm}$ Tris- $\mathrm{HCl}(\mathrm{pH} 8.3), 50$ $\mathrm{mM} \mathrm{KCl}, 0.1 \%$ gelatin, $1 \mathrm{~mm} \mathrm{MgCl} 2,200 \mu \mathrm{M}$ of each $\mathrm{dNTP}$, and 2 units of Replinase (New England Nuclear) for 35 cycles at $94^{\circ} \mathrm{C}$ for $1.5 \mathrm{~min}, 55^{\circ} \mathrm{C}$ for $2 \mathrm{~min}$, and $72^{\circ} \mathrm{C}$ for $3 \mathrm{~min}$ after an initial denaturation of $5 \mathrm{~min}$ at $95^{\circ} \mathrm{C}$. The products of the reaction were analyzed by agarose gel electrophoresis and, when needed, were purified by polyacrylamide gel electrophoresis and electroelution. A major fragment $(>80 \%$ of products) of $\sim 550 \mathrm{bp}$ was obtained (not shown). This size correlates with the predicted size of the PCR product if the C. crescentus $\sigma^{54}$ has the equivalent number of amino acids between and including the two conserved motifs as do $\sigma^{54}$ proteins from other bacteria (181 amino acids, $543 \mathrm{bp}$ ). To ensure that this 550 -bp fragment was rpoN DNA, we used it as a template for PCR with oligonucleotides encoding ELKYFF and MHEST / which correspond to se- 
quences that should be internal to the 550-bp fragment), respectively, with oligonucleotide encoding ARRTVAKYR as primers. In this case, the annealing was done at $45^{\circ} \mathrm{C}$. These reactions produced the expected 190- and 230-bp fragments, respectively.

Construction and screening of the $\mathrm{C}$. crescentus $\lambda Z A P$ library and screening of $a \mathrm{C}$. crescentus cosmid library

Chromosomal DNA was purified from $500 \mathrm{ml}$ of a NA1000 culture at an $\mathrm{OD}_{660}$ of 0.9 . The cell pellet was washed once and resuspended in $8 \mathrm{ml}$ of $0.1 \mathrm{M} \mathrm{NaCl}$ and $0.1 \mathrm{M}$ EDTA. Lysozyme was added to a final concentration of $1 \mathrm{mg} / \mathrm{ml}$, and the mixture was incubated for $15 \mathrm{~min}$ at room temperature. Sarkosyl $(160 \mu \mathrm{l}$ of a $20 \%$ solution) and proteinase $\mathrm{K}(20 \mu \mathrm{l}$ of a $20 \mathrm{mg} / \mathrm{ml}$ solution) were added, and the mixture was incubated at $37^{\circ} \mathrm{C}$ for $1 \mathrm{hr}$ and extracted twice with phenol equilibrated with $2 \times$ SSC. The DNA was precipitated and centrifuged. The pelleted DNA was resuspended in TE, incubated for $1 \mathrm{hr}$ at $37^{\circ} \mathrm{C}$ with $50 \mu \mathrm{g} / \mathrm{ml}$ of RNase A, extracted with phenol, and precipitated. The DNA pellet was resuspended in TE, extracted with chloroformisoamyl alcohol [24:1(vol/vol)], and precipitated. The DNA pellet was resuspended in $10 \mathrm{~mm}$ Tris- $\mathrm{HCl}(\mathrm{pH} 8.0), 0.1 \mathrm{~mm}$ EDTA, dialyzed against the same buffer, and stored at $4^{\circ} \mathrm{C}$.

For construction of the $\lambda$ ZAP library, the DNA was sheared by sonication, and fragments between 2.0 and $2.5 \mathrm{~kb}$ were purified by preparative agarose gel electrophoresis and electroelution. The ends were blunted with T4 DNA polymerase, and the DNA was methylated with EcoRI methylase using conditions described by the manufacturer. EcoRI linkers [GGAATTCC (Bethesda Research Laboratories|] were ligated to the methylated DNA, and the ligation products were digested with EcoRI and purified by agarose gel electrophoresis and electroelution. The DNA was then ligated to $\lambda Z A P$ arms using the Predigested Lambda ZAP II/EcoRI cloning kit, and the ligation products were packaged using the Gigapack Gold II kit (both from Stratagene) according to the manufacturer's instructions. The library $\left(3.5 \times 10^{5} \mathrm{pfu}, 92 \%\right.$ of which contained inserts) was amplified to $5 \times 10^{10} \mathrm{pfu}$.

Approximately $10^{5}$ plaques were screened using a ${ }^{32} \mathrm{P}$-labeled $550-\mathrm{bp}$ PCR fragment and gave 70 positive signals. Plasmid was rescued from five clones, according to the manufacturer's instructions, and analyzed by restriction enzyme digestion. Four of these plasmids (pYB101, pYB102, pYB103, and pYB104) were independent but contained a common DNA region (not shown). The fifth clone was identical to pYB103.

A C. crescentus cosmid library (Alley et al. 1991) was also screened with the ${ }^{32} \mathrm{P}$-labeled 550-bp PCR fragment. Pools of 20 cosmids were digested with $\mathrm{BamHI}$, and the products were separated on an agarose gel and transferred to a nitrocellulose membrane. The positive pool was identified by Southern hybridization. The same procedure was repeated with the individual clones from the positive pool. One positive cosmid was obtained.

\section{Electron microscopy}

Cells were grown to mid-log phase in different media (see Fig. 5) and washed by centrifugation at $5000 \mathrm{rpm}$ for $5 \mathrm{~min}$ in an Eppendorf microcentrifuge and resuspended in one-fifth volume of PBS solution. Cells (5 $\mu$ l) were spotted onto carbon-coated grids and allowed to settle for $20 \mathrm{~min}$. The grids were blotted dry and washed once with water. The cells were stained with $1 \%$ uranyl acetate for $30 \mathrm{sec}$ and washed four times with water. They were examined in a Philips 300 electron microscope at $60 \mathrm{kV}$.

\section{Acknowledgments}

We thank M.R.K. Alley for help in planning the rpoN cloning strategy, Janine Maddock for her patience in teaching electron microscopy to Y.V.B., Peter Underhill and Joel Bellenson for help with DNA sequencing, and Julien Sage for technical assistance. We thank Mitch Singer, Lisa Kalman, Josie Yu, Jim Gober, and the members of the Shapiro laboratory for critical reading of the manuscript and for helpful discussions. We especially thank Bert Ely for the gift of strain SC1055, for sharing unpublished data, and for very helpful discussions. We are grateful to Austin Newton, M.R.K. Alley, Wei Zhuang, Kim Quon, Josie $\mathrm{Yu}$, and Jim Gober for sharing unpublished data. This investigation was supported by U.S. Public Health Service grant GM32506 from the National Institutes of Health and grant NP938B from the American Cancer Society. Y.V.B. was supported by postdoctoral fellowships from the National Science and Engineering Research Council (NSERC) and the Medical Research Council (MRC) of Canada.

The publication costs of this article were defrayed in part by payment of page charges. This article must therefore be hereby marked "advertisement" in accordance with 18 USC section 1734 solely to indicate this fact.

\section{References}

Albright, L.M., E. Huala, and F. Ausubel. 1989a. Prokaryotic signal transduction mediated by sensor and regulator pairs. Annu. Rev. Genet. 23: 311-336.

Albright, L.M., C.W. Ronson, B.T. Nixon, and F.M. Ausubel. $1989 \mathrm{~b}$. Identification of a gene linked to Rhizobium meliloti $n \operatorname{tr} A$ whose product is homologous to a family of ATP-binding proteins. I. Bacteriol. 171: 1932-1941.

Alley, M.R.K., S.L. Gomes, W. Alexander, and L. Shapiro. 1991. Genetic analysis of a temporally transcribed chemotaxis gene cluster in Caulobacter crescentus. Genetics 129: 333342 .

Alley, M.R.K., J.R. Maddock, and L. Shapiro. 1992. Polar localization of a bacterial chemoreceptor. Genes \& Dev. 6: 825836.

Alting-Mees, M.A. and J.M. Short. 1989. pBluescript II: Gene mapping vectors. Nucleic Acids Res. 17: 9494.

Anba, J., M. Bidaud, M.L. Vasil, and A. Lazdunski. 1990. Nucleotide sequence of the Pseudomonas aeruginosa phoB gene, the regulation gene for the phosphate regulon. I. Bacteriol. 172: 4685-4689.

Ausubel, F.M., R. Brent, R.E. Kingston, D. Moore, J.G. Seidman, J.A. Smith, and K. Struhl, eds. 1989. Current protocols in molecular biology. John Wiley/Greene, New York.

Berger, D.K., D.R. Woods, and D.R. Rawlings. 1990. Complementation of an Escherichia coli $\sigma^{54}(\mathrm{~N} \operatorname{trA})$-dependent formate hydrogenase activity by a cloned Thiobacillus ferrooxidans ntrA gene. J. Bacteriol. 172: 4399-4406.

Bourret, R.B., K.A. Borkovitch, and M. Simon. 1991. Signal transduction pathways involving protein phosphorylation in prokaryotes. Annu. Rev. Biochem. 60: 401-441.

Brun, Y.V., R. Breton, and J. Lapointe. 1991. Large sequencing projects using rapidly prepared double-stranded plasmid DNA. DNA Sequence 1: 285-289.

Débarbouille, M., I. Martin-Verstraete, F. Kunst, and G. Rapoport. 1991. The Bacillus subtilis sigL gene encodes an equivalent of $\sigma^{54}$ from gram negative bacteria. Proc. Natl. Acad. Sci. 88: 9092-9096.

Devereux, D., P. Haeberli, and O. Smithies. 1984. A comprehensive set of sequence analysis program for the Vax. $\mathrm{Nu}$ cleic Acids Res. 12: 387-395. 
Dingwall, A. and L. Shapiro. 1989. Rate, origin, and bidirectionality of Caulobacter chromosome replication as determined by pulsed-field gel electrophoresis. Proc. Natl. Acad. Sci. 86: 119-123.

Dingwall, A., J.W. Gober, and L. Shapiro. 1990. Identification of a Caulobacter basal body structural gene and a cis-acting site required for activation of transcription. I. Bacteriol. 172: 6066-6076.

Dingwall, A., D. Garman, and L. Shapiro. 1992a. Organization and ordered expression of flagellar basal body rod and ring proteins. I. Mol. Biol. (in press).

Dingwall, A., W.-Y. Zhuang, K. Quon, and L. Shapiro. 1992b. Expression of an early gene in the flagellar regulatory hierarchy is sensitive to an interruption in DNA replication. $J$. Bacteriol. 174: 1760-1768.

Ely, B. and T.W. Ely. 1989. Use of pulsed field electrophoresis and transposon mutagenesis to estimate the minimal number of genes required for motility in Caulobacter crescentus. Genetics 123: 649-654.

Ely, B., R.H. Croft, and C.J. Gerardot. 1984. Genetic mapping of genes required for motility in Caulobacter crescentus. Genetics 108: 523-532.

Evinger, M. and N. Agabian. 1977. Envelope-associated nucleoid from Caulobacter crescentus stalked and swarmer cells. I. Bacteriol. 132: 294-301.

Ferber, D.M. and B. Ely. 1982. Resistance to amino acid inhibition in Caulobacter crescentus. Mol. \& Gen. Genet. 187: 446-452.

Filloux, A., M. Bally, C. Soscia, M. Murgier, and A. Lazdunski. 1988. Phosphate regulation in Pseudomonas aeruginosa: Cloning of the alkaline phosphatase gene and identification of phoB- and phoR-like genes. Mol. \& Gen. Genet. 212: 510 513.

Fukuda, A., H. Iba, and Y. Okada. 1977. Stalkless mutants of Caulobacter crescentus. I. Bacteriol. 131: 280-287.

Gober, J.W. and L. Shapiro. 1991. Temporal and spacial regulation of developmentally expressed genes in Caulobacter. BioEssays 13: 277-283.

- 1992. A developmentally regulated Caulobacter flagellar promoter is activated by $3^{\prime}$ enhancer and IHF binding elements. Mol. Biol. Cell 3: 913-926.

Gober, J.W., H. Xu, A. Dingwall, and L. Shapiro. 1991. Identification of cis-and trans-elements involved in the timed control of Caulobacter flagellar gene. J. Mol. Biol. 217: 247-257.

Gomes, S.L. and L. Shapiro. 1984. Differential expression and positioning of chemotaxis methylation proteins in Caulobacter. J. Mol. Biol. 177: 551-568.

Hanahan, D. 1985. Techniques for transformation of $E$. coli. In DNA cloning: A practical approach (ed. D.M. Glover), vol. 1, p. 109. IRL Press, Oxford, England.

Inouye, S., M. Yamada, A. Nakazawa, and T. Nakazawa. 1989. Cloning and sequence analysis of the ntrA (rpoN) gene of Pseudomonas putida. Gene 85: 145-152.

Johnson, R.C. and B. Ely. 1977. Isolation of spontaneously derived mutants of Caulobacter crescentus. Genetics 86: 2532.

Johnson, R.C. and W. Reznikoff. 1983. DNA sequences at the ends of transposon Tn5 required for transposition. Nature 304: 280-282.

Jones, R. and R. Haselkorn. 1989. The DNA sequence of the Rhodobacter capsulatus $n \operatorname{tr} A, n \operatorname{tr} B$ and $n t r C$ genes analogues required for nitrogen fixation. Mol. \& Gen. Genet. 215: 507-516.

Kullik, I., S. Fritsche, H. Knobel, J. Sanjuan, H. Hennecke, and H.-M. Fischer. 1991. Bradyrhizobium japonicum has two differentially regulated, functional homologs of the $\sigma^{54}$ gene
(rpoN). J. Bacteriol. 173: 1125-1138.

Kustu, S., E.J. Santero, D. Keener, D. Popham, and D. Weiss. 1989. Expression of $\sigma^{54}$ (ntrA)-dependent genes is probably united by a common mechanism. Microbiol. Rev. 53: 367376.

Kustu, S., A.K. North, and D.S. Weiss. 1991. Prokaryotic transcriptional enhancers and enhancer-binding proteins. Trends Biochem. Sci. 16: 397-402.

Losick, R. and P. Stragier. 1992. Crisscross regulation of celltype-specific gene expression during development in $B$. subtilis. Nature 355: 601-604.

Mansour, J. and L. Shapiro. 1981. Phospholipid biosynthesis is required for stalk elongation in Caulobacter crescentus. $J$. Bacteriol. 145: 1404-1412.

Marczynski, G. and L. Shapiro. 1992. Cell-cycle control of a cloned chromosomal origin of replication from Caulobacter crescentus. I. Mol. Biol. 226: 959-977.

Marino, W., S. Ammer, and L. Shapiro. 1976. Conditional surface structure mutants of Caulobacter crescentus temperature-sensitive flagella formation due to an altered flagellin monomer. J. Mol. Biol. 107: 115-130.

Merrick, M.J. and J.R. Coppard. 1989. Mutations in genes downstream of the rpoN gene (encoding $\sigma^{54}$ ) of Klebsiella pneumoniae affect expression from $\sigma^{54}$-dependent promoters. Mol. Microbiol. 3: 1763-1775.

Merrick, M.J. and J.R. Gibbins. 1985. The nucleotide sequence of the nitrogen-regulation gene ntrA of Klebsiella pneumoniae and comparison with conserved features in bacterial RNA polymerase sigma factors. Nucleic Acids Res. 13: 7607-7620.

Milhausen, M. and N. Agabian. 1983. Caulobacter flagellin mRNA segregates asymmetrically at cell division. Nature 302: 630-632.

Minnich, S.A. and A. Newton. 1987. Promoter mapping and cell cycle regulation of flagellin gene transcription in Caulobacter crescentus. Proc. Natl. Acad. Sci. 84: 1142-1146.

Mullin, D.A. and A. Newton. 1989. Ntr-like promoters and upstream regulatory sequence ftr are required for transcription of a developmentally regulated Caulobacter crescentus flagellar gene. I. Bacteriol. 171: 3218-3227.

Mullin, D., S. Minnich, S. Chen, and A. Newton. 1987. A set of positively regulated flagellar gene promoters in Caulobacter crescentus with sequence homology to the nif gene promoters of Klebsiella pneumoniae. I. Mol. Biol. 195: 939-943.

Ninfa, A.J., D.A. Mullin, G. Ramakrishnan, and A. Newton. 1989. Escherichia coli $\sigma^{54}$ RNA polymerase recognizes Caulobacter crescentus flbG and flaN flagellar gene promoters in vitro. J. Bacteriol. 171: 383-391.

Osley, M.A. and A. Newton. 1977. Mutational analysis of developmental control in Caulobacter crescentus. Proc. Natl. Acad. Sci. 74: 124-128.

Poindexter, J.S. 1964. Biological properties and classification of the Caulobacter group. Bacteriol. Rev. 28: 231-295.

- 1984. The role of calcium in stalk development and in phosphate acquisition in Caulobacter crescentus. Arch. Microbiol. 138: 140-152.

Popham, D.L., D. Szeto, J. Keener, and S. Kustu. 1989. Function of a bacterial activation protein that binds to transcriptional enhancers. Science 243: 629-635.

Ramakrishnan, G. and A. Newton. 1990. FlbD of Caulobacter crescentus is a homologue of the $\operatorname{Ntr} C\left(\mathrm{NR}_{1}\right)$ protein and activates $\sigma^{54}$-dependent flagellar gene promoters. Proc. Natl. Acad. Sci. 87: 2369-2373.

Ramakrishnan, G., J.-L. Zhao, and A. Newton. 1991. The cellcycle regulated flagellar gene $f l b F$ of Caulobacter crescentus is homologous to a virulence locus $(1 \mathrm{crD})$ of Yersinia pestis. 
Brun and Shapiro

I. Bacteriol. 173: 7283-7292.

Rao, N.N. and A. Torriani. 1990. Molecular aspects of phosphate transport in Escherichia coli. Mol. Microbiol. 4: 10831090.

Sambrook, J., E.F. Fritsch, and T. Maniatis. 1989. Molecular cloning: A laboratory manual. Cold Spring Harbor Laboratory Press, Cold Spring Harbor, New York.

Sanders, L.A., S. VanWay, and D.A. Mullin. 1992. Characterization of the Caulobacter crescentus flbF promoter and identification of the inferred FlbF product as a homolog of the LcrD protein from a Yersinia enterocolitica virulence plasmid. J. Bacteriol. 174: 857-866.

Sanger, F., S. Nicklen, and A.R. Coulson. 1977. DNA sequencing with chain-terminating inhibitors. Proc. Natl. Acad. Sci. 74: 5463-5467.

Sasse-Dwight, S. and J.D. Gralla. 1990. Role of eukaryotic-type functional domains found in the prokaryotic enhancer receptor factor $\sigma^{54}$. Cell 62: 945-954.

Schmidt, J.M. 1968. Stalk elongation in mutants of Caulobacter crescentus. J. Gen. Microbiol. 53: 291-298.

- 1969. Caulobacter crescentus mutants with short stalks. J. Bacteriol. 98: 816-817.

Schmidt, J.M. and R.Y. Stanier. 1966. The development of cellular stalks in bacteria. J. Cell Biol. 28: 423-436.

Schoenlein, P.V., L.S. Gallman, M.E. Winkler, and B. Ely. 1990. Nucleotide sequence of the Caulobacter crescentus flaF and $f l b T$ genes and an analysis of codon usage in organisms with $\mathrm{G}+\mathrm{C}$-rich genomes. Gene 93: 17-25.

Shapiro, L. 1985. Generation of polarity during Caulobacter cell differentiation. Annu. Rev. Cell Biol. 1: 173-207.

Short, J.M., J.M. Fernandez, J.A. Sorge, and W.D. Huse. 1988. $\lambda Z A P:$ A bacteriophage $\lambda$ expression vector with in vivo excision properties. Nucleic Acids Res. 16: 7583-7600.

Simon, R., U. Priefer, and A. Puhler. 1983. A broad host range mobilization system for in vivo genetic engineering: Transposon mutagenesis in Gram-negative bacteria. Biotechnology 1: 784-791.

Sommer, J.M. and A. Newton. 1989. Turning off flagellum rotation requires the pleiotropic gene pleD: pleA, ple $C$, and pleD define two morphogenic pathways in Caulobacter crescentus. J. Bacteriol. 171: 392-401.

Stock, J.B., A.J. Ninfa, and A.M. Stock. 1989. Protein phosphorylation and regulation of adaptative responses in bacteria. Microbiol. Rev. 53: 450-490.

Stove, J.L. and R.Y. Stanier. 1962. Cellular differentiation in stalked bacteria. Nature 196: 1189-1192.

Tax, R. 1978. Age distribution of Caulobacter cells in an exponential population. I. Bacteriol. 135: 16-17.

Thöny, B. and H. Hennecke. 1989. The $-24 /-12$ promoter comes of age. FEMS Microbiol. Rev. 63: 341-358.

van Slooten, J.C., E. Cervantes, W.J. Broughton, C.H. Wong, and J. Stanley. 1990. Sequence analysis of the rpoN sigma factor gene of Rhizobium sp. strain NGR234, a primary coregulator of symbiosis. I. Bacteriol. 172: 5563-5574.

Walker, S.G., R.E.W. Hancock, and J. Smit. 1991. Expression in Caulobacter crescentus of the phosphate-starvation-inducible porin OprP of Pseudomonas aeruginosa. FEMS Microbiol. Lett. 77: 217-222.

Wanner, B.L. 1987. Phosphate regulation of gene expression in Escherichia coli. In Escherichia coli and Salmonella typhimurium cellular and molecular biology (ed. F. Neidhardt), pp. 1386-1409. American Society for Microbiology, Washington, D.C.

Yu, J. and L. Shapiro. 1992. Early C. crescentus switch genes fliL and fliM are required for flagellar gene expression and normal cell division. J. Bacteriol. 174: 3327-3338. 


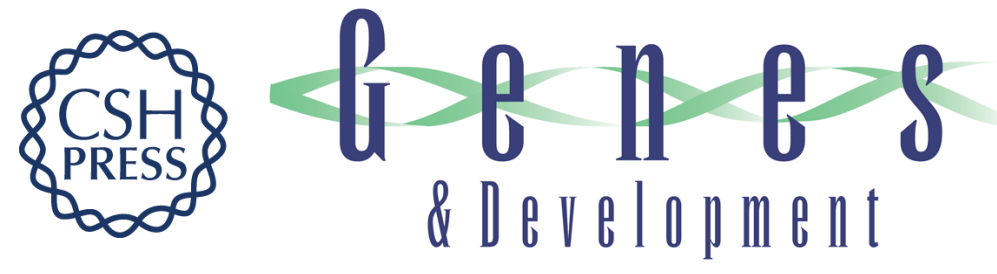

\section{A temporally controlled sigma-factor is required for polar morphogenesis and normal cell division in Caulobacter.}

$Y \vee$ Brun and L Shapiro

Genes Dev. 1992, 6:

Access the most recent version at doi:10.1101/gad.6.12a.2395

References This article cites 67 articles, 34 of which can be accessed free at:

http://genesdev.cshlp.org/content/6/12a/2395.full.html\#ref-list-1

License

Email Alerting

Service

Receive free email alerts when new articles cite this article - sign up in the box at the top right corner of the article or click here.

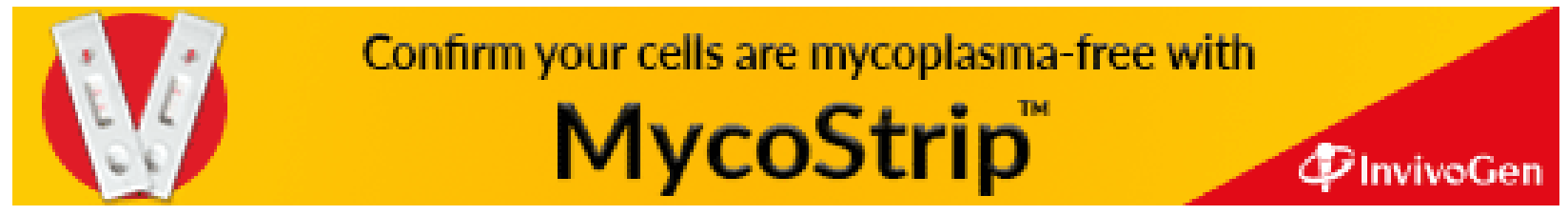

